\title{
Food biotechnology
}

DOI: http://doi.org/10.20914/2310-1202-2020-4-54-59 УДК 632.952

Оригинальная статья/Research article Open Access Available online at vestnik-vsuet.ru

\begin{tabular}{c} 
Токсичность новых фунгицидов для эукариотических \\
\hline \hline микроорганизмов, изолированных из кишечника продовольственно \\
значимого опылителя овощных культур Bombus terrestris $L$. \\
\hline \hline
\end{tabular}

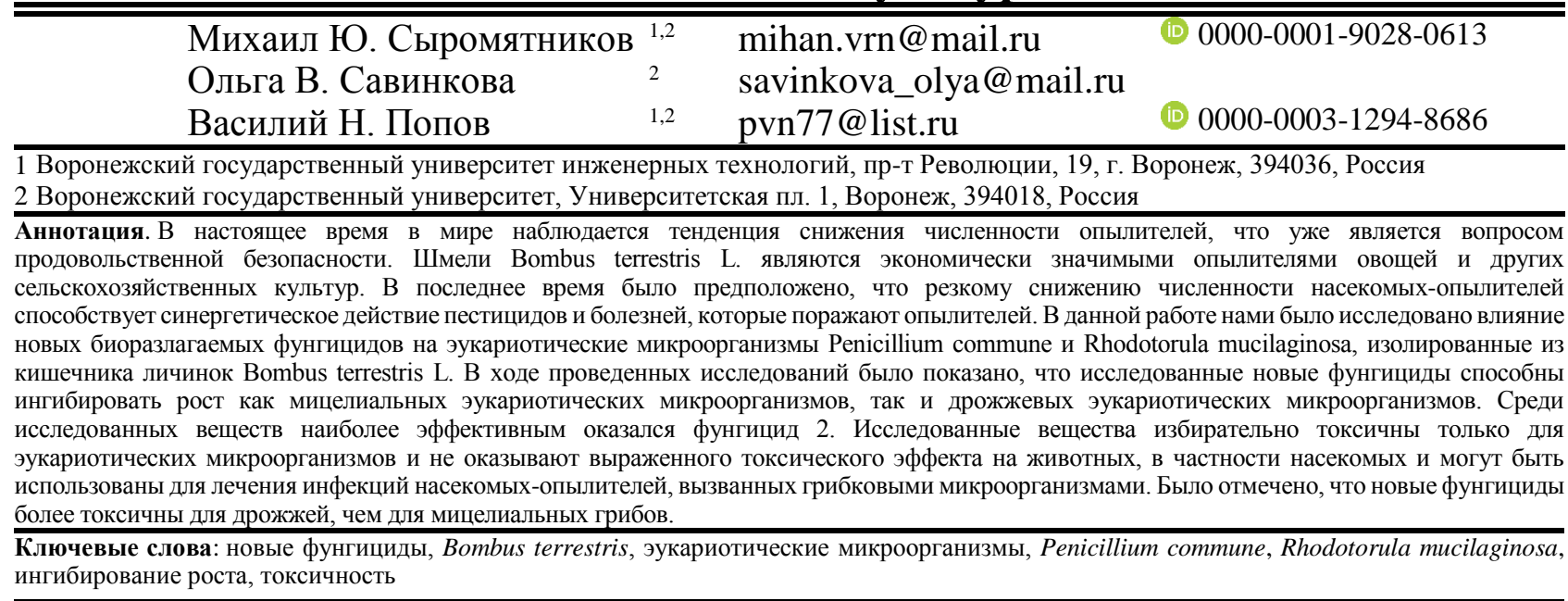

Toxicity of new fungicides for eukaryotic microorganisms isolated from the gut of the food-important vegetable pollinator Bombus terrestris $L$.

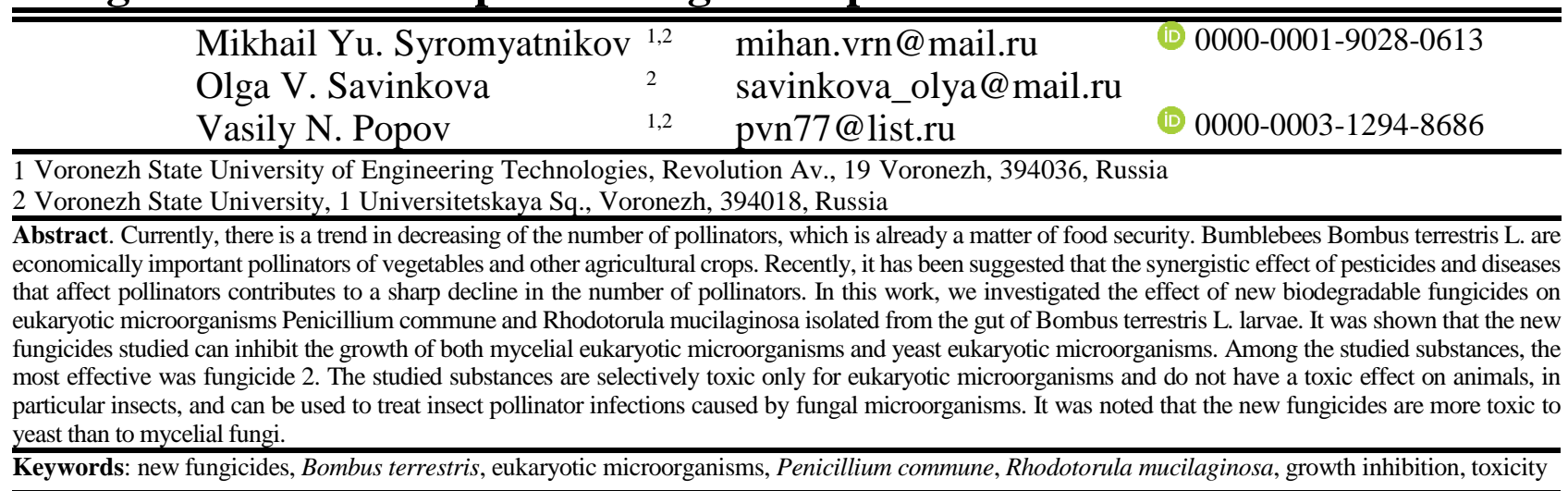

\section{Введение}

В настоящее время в мире наблюдается тенденция снижения численности опылителей [1-3]. Вымирание шмелей и пчел уже является вопросом продовольственной безопасности [4] поскольку опыление насекомыми является обязательным условием получения урожая энтомофильных культур потребляемых в пищу человеком. Одной из возможных причин этому является токсическое действие пестицидов [5-7].

\section{Для цитирования}

Сыромятников М.Ю., Савинкова О.В., Попов В.Н. Токсичность новых фунгицидов для эукариотических микроорганизмов, изолированных из кишечника продовольственно значимого опылителя овощных культур Bombus terrestris L. // Вестник ВГУИТ. 2020. Т. 82. № 4 C. 54-59. doi:10.20914/2310-1202-2020-4-54-59

(C) 2021, Сыромятников M.Ю. и др / Syromyatnikov M.Yu. et al.
Было отмечено, что фунгициды оказывают синергетический эффект при их одновременном действии с неоникотиноидами [8-11]. Существенная корреляция была найдена между воздействием фунгицидов и коллапсом пчелиных семей [6]. Пчелы, которые были подвержены действию фунгицидов, снижали общую продукцию АТФ [12]. Исследования влияния пестицидов на насекомых в основном касаются оценки их влияния на смертность, плодовитость и физиологические параметры.

For citation

Syromyatnikov M.Yu., Savinkova O.V., Popov V.N. Toxicity of new fungicides for eukaryotic microorganisms isolated from the gut of the foodimportant vegetable pollinator Bombus terrestris L.. Vestnik VGUIT [Proceedings of VSUET]. 2020. vol. 82. no. 4. pp. 54-59. (in Russian). doi:10.20914/2310-1202-2020-4-54-59

This is an open access article distributed under the terms of the Creative Commons Attribution 4.0 International License 
В последнее время было предположено, что резкому снижению численности насекомыхопылителей способствует синергетическое действие пестицидов и болезней, которые поражают опылителей [13-15]. Пестициды снижают общий иммунитет насекомых, что приводит к их повышенной восприимчивости к патогенам. Среди патогенов важнейших опылителей выделяют эукариотические микроорганизмы (патогены грибковой природы). Актуальным в настоящее время является поиск фунгицидов, которые способны эффективно уничтожать различные грибковые патогены, но при этом не причинять вреда полезным насекомым, таким как пчелы и шмели. В данной работе нами было исследовано влияние новых биоразлагаемых фунгицидов на эукариотические микроорганизмы, изолированные из личинок шмелей Bombus terrestris $L$. Кроме того, было оценена токсичность данных соединений на шмелей.

\section{Материалы и методы}

В качестве объектов исследования было выбрано 4 вновь синтезированных фунгицида, разработанных в НИИ Органической химии им. Зелинского (г. Москва, Россия):

- фунгицид 1-7-Hexyl-1,4-dimethyl-2,3,5,6tetraoxabicyclo[2.2.1] heptanes;

- фунгицид 2-7-(1-Adamantyl)-1,4-dimethyl2,3,5,6-tetraoxabicyclo[2.2.1] heptanes;

- фунгицид 3-7-Isopentyl-1,4-dimethyl2,3,5,6-tetraoxabicyclo[2.2.1] heptanes;

- фунгицид 4-3-(4-Methoxyphenyl)-6,7 a-dimethyltetrahydro-3H,4H-3,6-epoxy[1,2] dioxolo[3,4-b] pyran.

Самцы и личинки шмелей $B$. terrestris L. были использованы для исследования влияния фунгицидов.

Посев содержимого кишечника личинок шмелей осуществляли на среду Сабуро: панкреатический гидролизат рыбной муки - 10 г/л; панкреатический гидролизат казеина - 10 г/л; дрожжевой экстракт - 2 г/л; $\mathrm{NaH}_{2} \mathrm{PO}_{4}-2$ г/л; Д-глюкоза - 40 г/л; агар микробиологический - 10 г/л; $\mathrm{pH}$ 6,0. Для подавления роста посторонней микрофлоры в среду перед посевом вносили $0,1 \%$ раствора хлорамфеникола.

Для испытания на фунгицидную активность наводили растворы веществ в ДМСО. Полученные растворы добавили в разогретую до $50^{\circ} \mathrm{C}$ среду Сабуро. Приготовленные таким образом среды разлили по 15 мл в чашки Петри с внутренним диаметром 9 см.

Поверхность среды инокулировали кусочками мицелия трехдневной культуры грибов либо 100 мкл культуры дрожжей. Чашки Петри помещали в термостат при $25^{\circ} \mathrm{C}$ и держали в течение 72 часов. Затем измеряли диаметр колоний мицелиального микроорганизма либо осуществляли подсчет выросших колоний дрожжевого микроорганизма.

ДНК выделяли из выросших на среде Сабуро колоний с использованием набора Проба-ГС (ДНКтехнология, Россия). ДНК выделяли в соответствии с протоколом, приложенным к набору.
Полимеразная цепная реакция проводилась с использованием Таq-полимеразы на приборе Mastercycler personal (Eppendorf, Германия). Смешивали в пробирке 0,25 мл следующие компоненты: $5 \mathrm{X}$ реакционная смесь (Евроген, Россия) - 5 мкл; 5 мкМ прямой праймер - 1 мкл; 5 мкМ обратный праймер - 1 мкл; ДНК - 2 мкл; деионизованная вода - до 25 мкл. Использовали следующий температурный цикл: $94{ }^{\circ} \mathrm{C} 4$ мин, 35 циклов: $94{ }^{\circ} \mathrm{C} 30$ сек $54{ }^{\circ} \mathrm{C} 30$ сек, $72{ }^{\circ} \mathrm{C} 45$ сек, конечная элонгация $72{ }^{\circ} \mathrm{C}$ 10 мин. В качестве праймеров использовали следующие: прямой ITS1TCCGTAGGTGAACCTGCGG, обратный ITS4TCCTCCGCTTATTGATATGC [16]. Визуализацию продуктов ПЦР проводили с помощью электрофореза в $2 \%$ агарозном геле.

Извлечение из агарозного геля и очистку ампликона проводили с помощью коммерчески доступного набора Cleanup Standard (Евроген, Россия). Секвенирование очищенных продуктов ПЦР проводилось на генетическом анализаторе Applied Biosystems 3730 с использованием BigDye Terminator v3.1 Cycle Sequencing Kit. B качестве праймеров для секвенирования использовались те же, что и для амплификации целевого фрагмента (ITS1 и ITS4).

Для исследования токсичности новых фунгицидов для насекомых исследуемые вещества добавляли в 500 мкл ДМСО, после чего полученный раствор разбавляли в 10 мл дистилированной воды. В качестве контрольного раствора использовали раствор дистиллированной воды (10 мл) в который предварительно добавляли 500 мкл ДМСО. Шмелей аккуратно с помощью пинцета в течение 1 сек помещали в пробирку с раствором. После чего их держали в течение 2 часов в специализированном садке с фильтровальной бумагой на дне садка для того чтобы они обсохли. Далее шмелей помещали в цилиндрические садки (диаметр- 14 см, высота $-7 \mathrm{~cm}$ ) с сетчатым дном и крышкой, по 10 шмелей в каждом садке. Инвертированный сахарный сироп (60\%) использовали в качестве корма. Шмели содержались при температуре $27-28,5^{\circ} \mathrm{C}$ и при влажности воздуха 55-68\%.

Для измерения полетной активности шмели (3 шт.) помещались в прозрачную камеру: длина 25 см, ширина 15 см, высота 20 см. Для освещения использовали лампу дневного света. Далее каждые 5 сек регистрировали количество шмелей, находящихся в состоянии полёта. Измерение проводили в течение 20 мин. После чего высчитывали среднее количество шмелей, которые находились в состоянии полета в течение этого времени.

\section{Результаты и обсуждение}

Первоначально содержимое кишечника личинок шмеля высевали на универсальную питательную среду для грибов. По истечении 3-5 суток отбирали отдельные колонии, выделяли из них ДНК и осуществляли амплификацию маркерного для грибов региона (ITS1 и ITS2), после чего амплифицированные области 
секвенировали. Полученные нуклеотидные последовательности сопоставляли с международной системой GenBank. В результате были идентифицированы следующие эукариотические микроорганизмы: Lachancea thermotolerans, Naganishia adeliensis, Penicillium commune, Rhodotorula mucilaginosa. При этом при анализе 10 образцов личинок шмелей изолированных из различных колоний, было выявлено, что наиболее часто встречаемые в кишечнике личинок шмелей эукариотические микроорганизмы были $P$. commune ( $80 \%$ образцов) и $R$. mucilaginosa $(70 \%$ образцов). Поскольку эти эукариотические микроорганизмы наиболее часто встречались в кишечнике личинок шмелей и в норме в кишечнике личинок не должно содержаться каких-либо эукариотических микроорганизмов (как мицелиальных грибов, так и дрожжей), дальнейшие исследования новых фунгицидов проводились с данными микроорганизмами.

Исследуемые новые фунгициды добавляли в питательную среду в концентрациях 0,005 ; 0,$02 ; 0,05$ и 0,1 г/л и затем вносили на чашки Петри. На рисунке 1 изображено влияние различных концентраций фунгицида 1 на диаметр мицелиального гриба $P$. commune

При внесении фунгицида № 1 в концентрации 0,005 г./л игибирующего действия на рост мицелиального микроорганизма не было (по отношению к контрольному образцу, в котором препарат отсутствует). При увеличении концентрации фунгицида, наблюдалось слабое ингибирование роста гриба. Максимальное ингибирование роста гриба (на 25\%) наблюдалось в концентрации фунгицида в питательной среде 0,1 г/л.

На рисунке 2 изображено влияние различных концентраций фунгицида 2 на диаметр

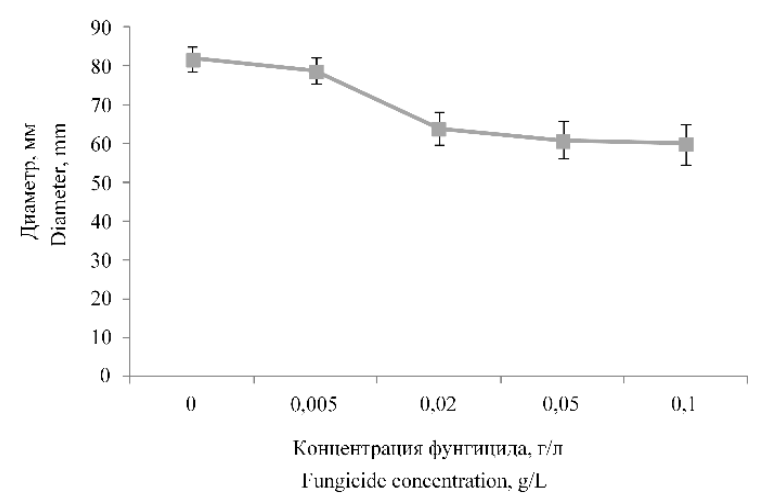

Рисунок 1. Влияние фунгицида 1 на рост гриба P. commune

Figure 1. Effect of fungicide 1 on the growth of the fungus $P$. commune мицелиального гриба. В концентрации 0,1 г/л данный фунгицид ингибировал рост $P$. commune на $48 \%$.

На рисунке 3 изображено влияние различных концентраций фунгицида 3 на диаметр мицелиального гриба. Небольшое ингибирование роста мицелиального гриба (на $18 \%$ ) наблюдалось уже при концентрации фунгицида 0,005 г./л. Однако затем, с повышением концентрации фунгицида, дальнейшего подавления роста гриба не наблюдалось.

При исследовании влияния фунгицида 4 на рост гриба P. commune было выявлен, что данный фунгицид достоверно снижает скорость роста гриба на $19 \%$ только в концентрации 0,05 и 0,1 г/л (рисунок 4).

Далее нами оценивалось ингибирующее действие новых фунгицидов на количество выросших колоний дрожжевого микроорганизма $R$. mucilaginosa. Так, фунгицид 1 в концентрации 0,1 г/л сокращал количество выросших колоний на $17 \%$ (рисунок 5).

Фунгицид 2 показал высокую активность против дрожжей $R$. mucilaginosa. Уже при концентрации фунгицида 0,005 г./л количество колоний дрожжей сократилось в два раза, а при концентрации $0,05 \%$ фунгицид полностью подавил рост колоний дрожжей (рисунок 6).

Слабый ингибирующий эффект на рост дрожжей R. mucilaginosa оказал фунгицид 3. В максимальной концентрации фунгицида количество колоний дрожжей уменьшилось только на 24\% (рисунок 7).

Фунгицид 4 показал высокую активность против дрожжей $R$. mucilaginosa в максимальной концентрации. В концентрации фунгицида 0,1 г/л количество колоний дрожжей сократилось в 16,4 раза (рисунок 8).

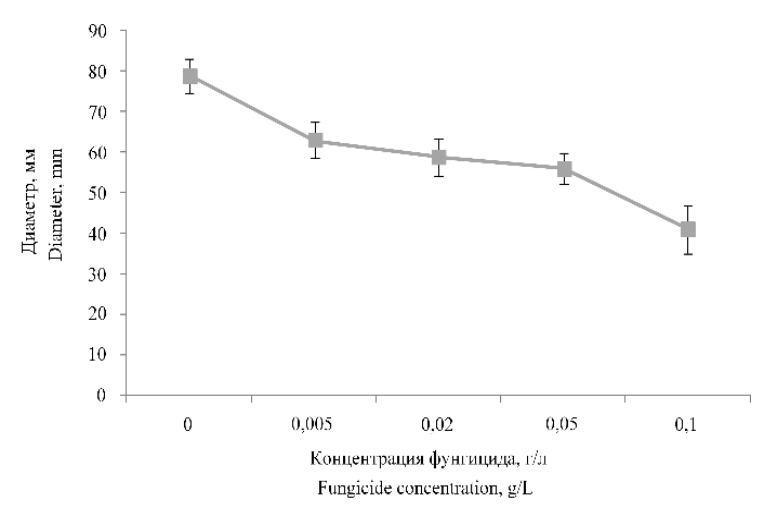

Рисунок 2. Влияние фунгицида 2 на рост гриба P. commune

Figure 2. Effect of fungicide 2 on the growth of the fungus $P$. commune 


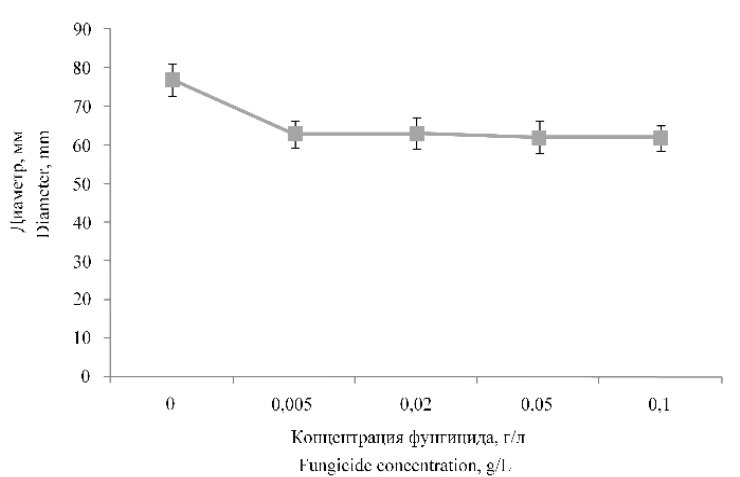

Рисунок 3. Влияние фунгицида 3 на рост гриба P. commune

Figure 3. Effect of fungicide 3 on the growth of the fungus $P$. commune

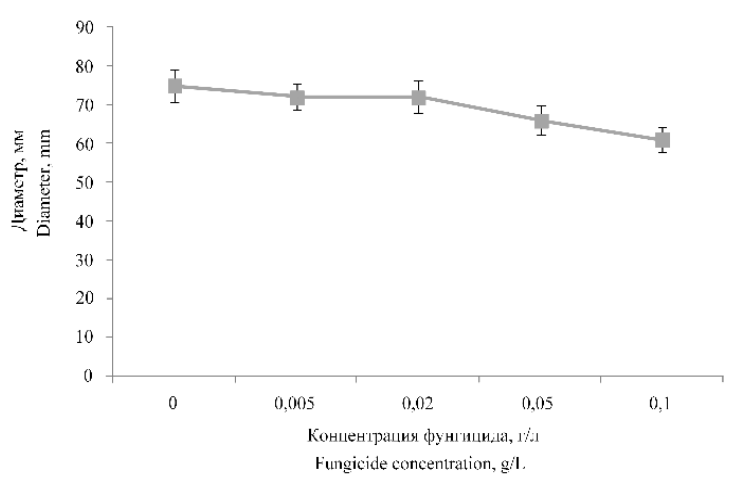

Рисунок 4. Влияние фунгицида 4 на рост гриба P. commune

Figure 4. Effect of fungicide 4 on the growth of the fungus $P$. commune

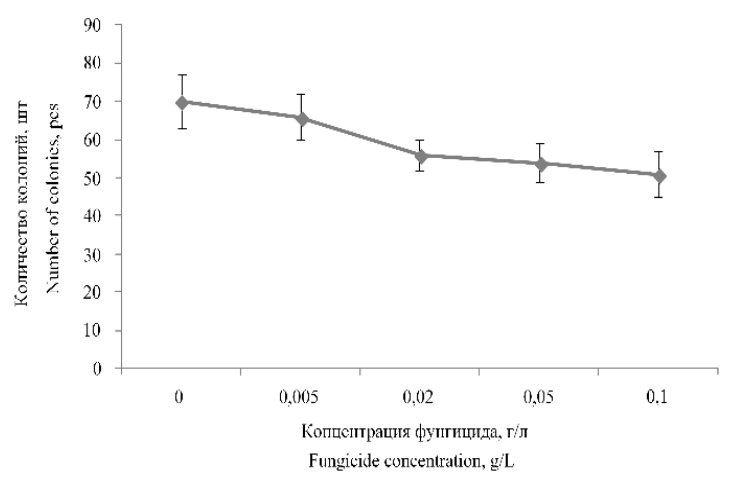

Рисунок 5. Влияние фунгицида 1 на количество колоний дрожжей $R$. mucilaginosa

Figure 5. Effect of fungicide 1 on the number of colonies of yeast $R$. mucilaginosa

На следующем этапе оценивалось влияние новых фунгицидов на полётную активность самцов шмелей. В ходе эксперимента было выявлено, что новые фунгициды даже в максимально возможной концентрации $(0,1$ г/л) не снижали полётную активность насекомых. В то время как классический фунгицид дифеноконазол снизил полётную активность B. terrestris L. в 1,43 раза. Гибель шмелей не вызвал ни один фунгицид.

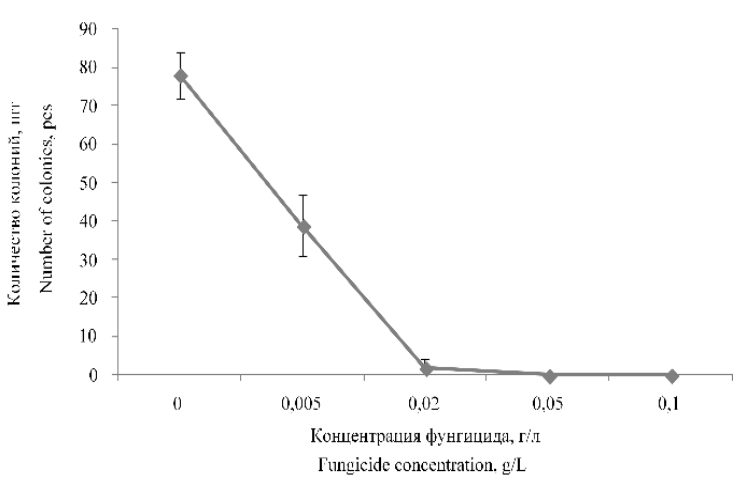

Рисунок 6. Влияние фунгицида 2 на количество колоний дрожжей $R$. mucilaginosa

Figure 6. Effect of fungicide 2 on the number of colonies of yeast $R$. mucilaginosa

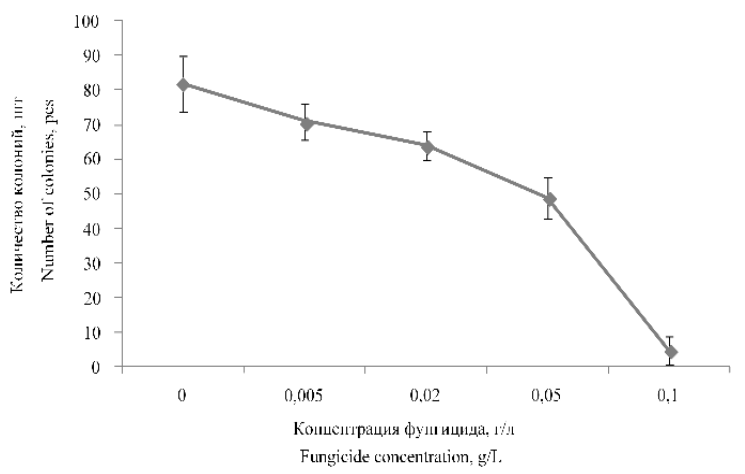

Рисунок 7. Влияние фунгицида 3 на количество колоний дрожжей $R$. mucilaginosa

Figure 7. Effect of fungicide 3 on the number of colonies of yeast $R$. mucilaginosa

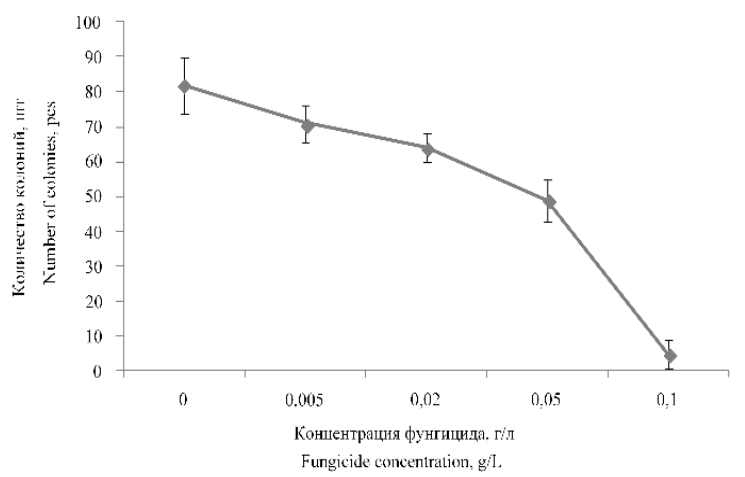

Рисунок 8. Влияние фунгицида 4 на количество колоний дрожжей $R$. mucilaginosa

Figure 8. Effect of fungicide 4 on the number of colonies of yeast $R$. mucilaginosa

Таким образом, нами было показано, что исследованные вещества (см. материалы и методы) имеют фунгицидную активность как по отношению к мицелиальным эукариотическим микроорганизмам, так и по отношении дрожжевым эукариотическим микроорганизмам. По отношению к дрожжевым микроорганизмам исследованные вещества оказывали более выраженную фунгицидную активность. Среди исследованных веществ наиболее эффективным 
оказался фунгицид 2 (7-(1-Adamantyl)-1,4-dimethyl2,3,5,6-tetraoxabicyclo[2.2.1]heptanes). Это вещество наиболее сильно подавляло рост $P$. commune (на $48 \%$ ) и полностью подавляло рост дрожжевого микроорганизма ( $R$. mucilaginosa).

Примечательно, что исследованные новые фунгициды не снижали полетную активность B. terrestris. Это говорит о том, что данные вещества избирательно токсичны только для грибов и не оказывают выраженного токсического эффекта на животных, в частности насекомых. Таким образом, они могут быть потенциальными эффективными препаратами для лечения инфекций насекомых-опылителей, вызванных грибковыми микроорганизмами.

\section{Заключение}

В ходе проведенных исследований было показано, что исследованные новые фунгициды способны ингибировать рост как мицелиальных эукариотических микроорганизмов, так и дрожжевых эукариотических микроорганизмов.
Среди исследованных веществ наиболее эффективным оказался фунгицид 2 (7-(1-Adamantyl)1,4-dimethyl-2,3,5,6-tetraoxabicyclo[2.2.1] heptanes). При этом исследованные вещества избирательно токсичны только для грибов и не оказывают выраженного токсического эффекта на животных, в частности насекомых и могут быть использованы для лечения инфекций насекомых-опылителей, вызванных грибковыми микроорганизмами. Таким образом, применение новых биоразлагаемых фунгицидов для лечения болезней шмелей, вызванных эукариотическими микроорганизмами, позволит получить экологически чистую овощную продукцию и, в целом, повысит продовольственную безопасность населения.

\section{Благодарность}

Работа выполнена в рамках нацпроекта «Наука» (проект FZGW-2020-0001, уникальный номер реестра государственных заданий 075001Х39782002) и при поддержке гранта Президента РФ для молодых кандидатов наук (проект МK-3173.2019.11)

\section{Литература}

1 Potts S.G., Biesmeijer J.C., Kremen C., Neumann P. et al. Global pollinator declines: Trends, impacts and drivers // Trends Ecol. Evol. 2010. V. 25(6). P. 345-353. doi: 10.1016/j.tree.2010.01.007

2 Rhodes C.J. Pollinator decline - an ecological calamity in the making? // Sci. Prog. 2018. V. 101(2). P. 121-160. doi: 10.3184/003685018X15202512854527

3 Thomann M., Imbert E., Devaux C., Cheptou P.O. Flowering plants under global pollinator decline // Trends Plant Sci. 2013. V. 18(7). P. 353-359. doi: 10.1016/j.tplants.2013.04.002

4 Klein A.M., Vaissiere B.E., Cane J.H., Steffan-Dewenter I. et al. Importance of pollinators in changing landscapes for world crops // Proc. Roy. Soc. B. 2007. V. 274(1608). P. 303-313. doi: 10.1098/rspb.2006.3721

5 Lu C., Warchol K.M., Callahan R.A. Sub-lethal exposure to neonicotinoids impaired honey bees winterization before proceeding to colony collapse disorder // Bulletin of Insectology. 2014. V. 67(1). P. 125-130.

6 Simon-Delso N, San Martin G, Bruneau E, Minsart L-A. et al. Honeybee colony disorder in crop areas: the role of pesticides and viruses // PLoS ONE. 2014. V. 9(7). e103073. doi: 10.1371/journal.pone.0103073

7 Bryden J, Gill R.J., Mitton R.A., Raine N.E. et al. Chronic sublethal stress causes bee colony failure // Ecol Lett. 2013. V. 16(12). P. 1463-1469. doi: 10.1111/ele.12188

8 Fisher A., Coleman C., Hoffmann C., Fritz B. et al. The Synergistic Effects of Almond Protection Fungicides on Honey Bee (Hymenoptera: Apidae) Forager Survival // J. Econ. Entomol. 2017. V. 110(3). P. 802-808. doi: 10.1093/jee/tox031

9 Raimets R., Karise R., Mand M., Kaart T. et al. Synergistic interactions between a variety of insecticides and an ergosterol biosynthesis inhibitor fungicide in dietary exposures of bumble bees (Bombus terrestris L.) // Pest Manag. Sci. 2018. V. 74(3). P. 541-546. doi: 10.1002/ps.4756

10 Zhu Y.C., Yao J.X., Adamczyk J., Luttrell R. Feeding toxicity and impact of imidacloprid formulation and mixtures with six representative pesticides at residue concentrations on honey bee physiology (Apis mellifera) // PLoS ONE. 2017. V. 12(6). e0178421. doi: 10.1371/journal.pone.0178421

11 Sgolastra F., Medrzycki P., Bortolotti L., Renzi M.T. et al. Synergistic mortality between a neonicotinoid insecticide and an ergosterol-biosynthesis-inhibiting fungicide in three bee species // Pest Manag. Sci. 2017. V. 73(6). P. 1236-1243. doi: 10.1002/ps.4449

12 Degrandi-Hoffman G., Chen Y., Dejong W.E., Chambers M.L. et al. Effects of Oral Exposure to Fungicides on Honey Bee Nutrition and Virus Levels // J Econ Entomol. 2015. V. 108(6). P. 2518-2528. doi: 10.1093/jee/tov251

13 Lopez J.H., Krainer S., Engert A., Schuehly W. et al. Sublethal pesticide doses negatively affect survival and the cellular responses in American foulbrood-infected honeybee larvae // Sci. ReP. 2017. V. 7. P. 40853. doi: 10.1038/srep40853

14 Grassl J., Holt S., Cremen N., Peso M. et al. Synergistic effects of pathogen and pesticide exposure on honey bee (Apis mellifera) survival and immunity // J. Invertebr. Pathol. 2018. V. 159. P. 78-86. doi: 10.1016/j.jip.2018.10.005

15 Aufauvre J., Biron D.G., Vidau C., Fontbonne R. et al. Parasite-insecticide interactions: A case study of Nosema ceranae and fipronil synergy on honeybee // Sci. ReP. 2012. V. 2. P. 326. doi: 10.1038/srep00326

16 White T.J., Bruns T., Lee S., Taylor J. Amplification and direct sequencing of fungal ribosomal RNA genes for phylogenetics // In: PCR Protocols: A Guide to Methods and Applications. New York: Academic Press. 1990. V. 18. P. 315-322. 


\section{References}

1 Potts S.G., Biesmeijer J.C., Kremen C., Neumann P. et al. Global pollinator declines: Trends, impacts and drivers. Trends Ecol. Evol. 2010. vol. 25. no. 6. pp. 345-353. doi: 10.1016/j.tree.2010.01.007

2 Rhodes C.J. Pollinator decline - an ecological calamity in the making? Sci. Prog. 2018. vol. 101. no. 2. pp. $121-160$. doi: 10.3184/003685018X15202512854527

3 Thomann M., Imbert E., Devaux C., Cheptou P.O. Flowering plants under global pollinator decline. Trends Plant Sci. 2013. vol. 18. no. 7. pp. 353-359. doi: 10.1016/j.tplants.2013.04.002

4 Klein A.M., Vaissiere B.E., Cane J.H., Steffan-Dewenter I. et al. Importance of pollinators in changing landscapes for world crops. Proc. Roy. Soc. B. 2007. vol. 274. no. 1608. pp. 303-313. doi: 10.1098/rspb.2006.3721

5 Lu C., Warchol K.M., Callahan R.A. Sub-lethal exposure to neonicotinoids impaired honey bees winterization before proceeding to colony collapse disorder. Bulletin of Insectology. 2014. vol. 67. no.1. pp. 125-130.

6 Simon-Delso N, San Martin G, Bruneau E, Minsart L-A. et al. Honeybee colony disorder in crop areas: the role of pesticides and viruses. PLoS ONE. 2014. vol. 9. no. 7. e103073. doi: 10.1371/journal.pone.0103073

7 Bryden J, Gill R.J., Mitton R.A., Raine N.E. et al. Chronic sublethal stress causes bee colony failure. Ecol Lett. 2013. vol. 16. no. 12. pp. 1463-1469. doi: 10.1111/ele.12188

8 Fisher A., Coleman C., Hoffmann C., Fritz B. et al. The Synergistic Effects of Almond Protection Fungicides on Honey Bee (Hymenoptera: Apidae) Forager Survival. J. Econ. Entomol. 2017. vol. 110. no. 3. pp. 802-808. doi: 10.1093/jee/tox031

9 Raimets R., Karise R., Mand M., Kaart T. et al. Synergistic interactions between a variety of insecticides and an ergosterol biosynthesis inhibitor fungicide in dietary exposures of bumble bees (Bombus terrestris L.). Pest Manag. Sci. 2018. vol. 74. no. 3. pp. 541-546. doi: 10.1002/ps.4756

10 Zhu Y.C., Yao J.X., Adamczyk J., Luttrell R. Feeding toxicity and impact of imidacloprid formulation and mixtures with six representative pesticides at residue concentrations on honey bee physiology (Apis mellifera). PLoS ONE. 2017. vol. 12. no.6. e0178421. doi: 10.1371/journal.pone.0178421

11 Sgolastra F., Medrzycki P., Bortolotti L., Renzi M.T. et al. Synergistic mortality between a neonicotinoid insecticide and an ergosterol-biosynthesis-inhibiting fungicide in three bee species. Pest Manag. Sci. 2017. vol. 73. no. 6. pp. 1236-1243. doi: 10.1002/ps.4449

12 Degrandi-Hoffman G., Chen Y., Dejong W.E., Chambers M.L. et al. Effects of Oral Exposure to Fungicides on Honey Bee Nutrition and Virus Levels. J Econ Entomol. 2015. vol. 108. no. 6. pp. 2518-2528. doi: 10.1093/jee/tov251

13 Lopez J.H., Krainer S., Engert A., Schuehly W. et al. Sublethal pesticide doses negatively affect survival and the cellular responses in American foulbrood-infected honeybee larvae. Sci. ReP. 2017. vol. 7. pp. 40853. doi: 10.1038/srep40853

14 Grassl J., Holt S., Cremen N., Peso M. et al. Synergistic effects of pathogen and pesticide exposure on honey bee (Apis mellifera) survival and immunity. J. Invertebr. Pathol. 2018. vol. 159. pp. 78-86. doi: 10.1016/j.jip.2018.10.005

15 Aufauvre J., Biron D.G., Vidau C., Fontbonne R. et al. Parasite-insecticide interactions: A case study of Nosema ceranae and fipronil synergy on honeybee. Sci. ReP. 2012. vol. 2. pp. 326. doi: 10.1038/srep00326

16 White T.J., Bruns T., Lee S., Taylor J. Amplification and direct sequencing of fungal ribosomal RNA genes for phylogenetics. In: PCR Protocols: A Guide to Methods and Applications. New York: Academic Press. 1990. vol. 18. pp. 315-322.

\section{Сведения об авторах}

Михаил Ю. Сыромятников к.б.н., доцент, ведущий научный сотрудник, лаборатория метагеномики и пищевых биотехнологий, Воронежский государственный университет инженерных технологий, ул. Сакко и Ванцетти, 72, г. Воронеж, 394036, Россия, mihan.vrn@mail.ru

(Dhttps://orcid.org/0000-0001-9028-0613

Ольга В. Савинкова аспирант, кафедра генетики, цитологии и биоинженерии, Воронежский государственный университет, Университетская пл. 1, г. Воронеж, 394018, Россия, savinkova_olya@mail.ru

Василий Н. Попов д.б.н., профессор, ректор, Воронежский государственный университет инженерных технологий, пр-т Революции, 19, г. Воронеж, 394036, Россия, pvn77@list.ru

(Dhttps://orcid.org/0000-0003-1294-8686

\section{Вклад авторов}

Михаил Ю. Сыромятников написал рукопись, корректировал её до подачи в редакцию и несет ответственность за плагиат Ольга В. Савинкова обзор литературных источников по исследуемой проблеме, провела эксперимент, выполнила расчёты Василий Н. Попов консультация в ходе исследования

\section{Information about authors}

Mikhail Yu. Syromyatnikov Cand. Sci. (Biol.), associate professor, leading researcher, laboratory of metagenomics and food biotechnologies, Voronezh State University of Engineering Technologies, 72 Sakko and Vanzetti str., Voronezh, 394036, Russia, mihan.vrn@mail.ru Dhttps://orcid.org/0000-0001-9028-0613

Olga V. Savinkova graduate student, genetics, cytology and bioengineering department, Voronezh State University, 1 Universitetskaya sq., Voronezh, 394018, Russia, savinkova_olya @ mail.ru

Vasily N. Popov Dr. Sci. (Biol.), professor, rector, Voronezh State University of Engineering Technologies, 19 Revolution Av., Voronezh, 394036, Russia, pvn77@list.ru (Dhttps://orcid.org/0000-0003-1294-8686

\section{Contribution}

Mikhail Yu. Syromyatnikov wrote the manuscript, correct it before filing in editing and is responsible for plagiarism

Olga V. Savinkova review of the literature on an investigated problem, conducted an experiment, performed computations

Vasily N. Popov consultation during the study

Conflict of interest

The authors declare no conflict of interest.

\begin{tabular}{ccc}
\hline Поступила 09/11/2020 & После редакции 21/11/2020 & Принята в печать 30/11/2020 \\
\hline Received 09/11/2020 & Accepted in revised 21/11/2020 & Accepted 30/11/2020 \\
\hline
\end{tabular}

